\title{
Perlindungan Hak Asasi Manusia Bagi Korban Kekerasan Seksual di Indonesia
}

\author{
Luh Made Khristianti Weda Tantri \\ khristiantiweda@gmail.com \\ Universitas Airlangga
}

\begin{abstract}
Keywords: $\quad$ Abstract
Human Rights; Self Protection from all forms of sexual violence is part of human rights, namely the right to Protection; Sexual individual safety, the right to freedom and personal security, and self-protection of the Violence. $\quad h o n o r$ and dignity of a person that are guaranteed by the constitution. The number of sexual violence that is increasing year after year is not proportional comparing to the low legal settlement obtained by victims of sexual violence. However, until now, there are no specific laws and regulations governing sexual violence In Indonesia. This research will discuss the protection of human rights for victims of sexual violence in Indonesia as an effort to protect human rights for the victims of sexual violence by using statute approach and conceptual approach. The results of this study conclude that laws related to sexual violence already exist but have not been able to provide comprehensive legal protection because there is no specific law on sexual violence.
\end{abstract}

Kata Kunci: Hak Abstrak

Asasi Manusia; Perlindungan dari segala bentuk kekerasan seksual merupakan bagian dari hak Perlindungan Diri; Kekerasan Seksual. asasi manusia yaitu hak atas keselamatan individu, hak kebebasan dan keamanan pribadi, dan perlindungan diri atas kehormatan dan martabat seseorang yang dijamin oleh konstitusi. Angka kekerasan seksual yang semakin meningkat dari tahun ke tahunnya tidak sebanding dengan rendahnya penyelesaian hukum yang didapat oleh korban-korban kekerasan sekual. Namun demikian, hingga kini belum ada peraturan perundang- undangan khusus yang mengatur tentang kekerasan seksual di Indonesia. Penelitian ini akan membahas tentang perlindungan bagi korban kekerasan seksual di Indonesia sebagai upaya perlindungan hak asasi manusia dengan menggunakan pendekatan perundangundangan dan pendekatan konseptual. Penelitian ini memperoleh kesimpulan bahwa peraturan perundang-undangan terkait kekerasan seksual sudah ada namun masih belum dapat memberikan perlindungan hukum yang komprehensif karena tidak adanya peraturan perundang-undangan khusus tentang kekerasan seksual.

Copyright ( 2021 Luh Made Khristianti Weda Tantri.
Published in Media Iuris. Published by Universitas Airlangga, Magister Ilmu Hukum.

\section{Pendahuluan}

Konsepsi negara Indonesia yang berdasarkan hukum telah tertuang pada

Pasal 1 ayat (3) Undang-Undang Dasar Negara Republik Indonesia Tahun 1945

(selanjutnya disebut UUD NRI Tahun 1945). Ide sentral rechtsstaat ada pada 
pengakuan terhadap hak asasi manusia (HAM). ${ }^{1}$ Pengakuan dan perlindungan terhadap HAM yang bertumpu pada prinsip kebebasan dan persamaan harus dijamin dan dipenuhi oleh negara.

Salah satu yang dijamin secara tegas oleh konstitusi adalah terkait kebebasan dari penyiksaan atau perbuatan yang merendahkan derajat martabat manusia yaitu yang terdapat dalam Pasal 28G ayat (2) UUD NRI Tahun 1945. Kekerasan seksual yang merupakan perbuatan yang merendahkan derajat martabat seseorang. Sehingga penghapusan terhadap segala bentuk kekerasan seksual merupakan keniscayaan dalam perlindungan atas hak untuk bebas dari perlakuan yang merendahkan derajat martabat seorang manusia. Namun, pada kenyataannya kasus-kasus kekerasan seksual terus saja terjadi dan seolah diabaikan oleh negara

Sejak 2008 hingga 2019 kekerasan terhadap perempuan telah meningkat sebanyak 792\%, yang artinya selama 12 tahun, kekerasan terhadap perempuan meningkat hampir 8 kali lipat. ${ }^{2}$ Sepanjang 2019 saja, Komisi Nasional Anti Kekerasan Terhadap Perempuan (Komnas Perempuan) mencatat 431.471 kasus kekerasan terhadap perempuan. ${ }^{3}$ Berdasarkan data yang tercatat tersebut, jenis kekerasan terhadap perempuan didominasi kekerasan pada ranah personal. Bentuk kekerasan yang terbanyak adalah kekerasan fisik dengan 43\% dari total kasus dan disusul kekerasan seksual dengan 25\% dari keseluruhan kasus kekerasan terhadap perempuan. ${ }^{4}$

Minimnya payung perlindungan hukum yang tersedia tidak sebanding dengan kompleksitas kasus-kasus kekerasan seksual menyebabkan adanya impunitas, keberulangan, dan rasa frustrasi para korban dalam menuntut hak atas keadilan, kebenaran, dan pemulihan. Banyaknya kasus kekerasan seksual yang terjadi tidak dibarengi dengan adanya instrumen hukum yang komprehensif. Perlindungan bagi perempuan Indonesia untuk terbebas dari kekerasan berbasis

\footnotetext{
${ }^{1}$ Bahder Johan Nasution, Negara Hukum Dan Hak Asasi Manusia (Mandar Maju 2018).

${ }^{2}$ Komnas Perempuan, Kekerasan Meningkat: Kebijakan Penghapusan Kekerasan Seksual Untuk Membangun Ruang Aman Bagi Perempuan Dan Anak Perempuan (Catatan Kekerasan Terhadap Perempuan Tahun 2019) (2020).

${ }^{3}$ ibid. [1].

${ }^{4}$ ibid.[13].
} 
gender masih belum menjadi perhatian serius dari negara. ${ }^{5}$ Perkembangan masyarakat yang begitu cepat tidak dapat diikuti dengan paradigma hukum baru, sehingga hukum menjadi tidak responsif terhadap persoalan-persoalan perempuan. ${ }^{6}$

Meskipun pada berbagai regulasi di Indonesia telah dikenal berbagai jenis terminologi yang menjelaskan tentang tindak pidana yang berhubungan dengan kekerasan seksual. Mulai dari kejahatan terhadap kesusilaan dalam Kitab Undang-Undang Hukum Pidana (selanjutnya disebut KUHP), kejahatan terhadap kehormatan dalam beberapa terjemahan KUHP, kejahatan seksual dalam Undang-Undang Nomor 35 Tahun 2014 tentang Perubahan Atas UndangUndang Nomor 23 Tahun 2002 tentang Perlindungan Anak (selanjutnya disebut UU Perlindungan Anak), kekerasan seksual dalam Undang-Undang Nomor 23 Tahun 2004 tentang Penghapusan Kekerasan Dalam Rumah Tangga (selanjutnya disebut UU PKDRT) dan Undang-Undang Nomor 44 Tahun 2008 tentang Pornografi (selanjutnya disebut UU Pornografi). ${ }^{7}$ Namun, sekalipun peraturan perundang- undangan di atas telah memuat berbagai tindak pidana yang berkaitan dengan kekerasan seksual, KUHP sendiri tidak memberikan pengertian khusus mengenai tindak pidana yang berhubungan dengan kekerasan seksual, melainkan langsung menjabarkannya dalam rumusan pasal. Begitu juga dengan UU Perlindungan Anak yang hanya merujuk kepada KUHP, Undang-Undang Nomor 21 Tahun 2007 tentang Pemberantasan Tindak Pidana Perdagangan Orang (selanjutnya disebut UU PTPPO) yang hanya mengatur kekerasan dalam konteks perdagangan manusia untuk tujuan eksploitasi seksual, dan UU PKDRT yang tidak memberikan pengertian yang jelas tentang kekerasan seksual. ${ }^{8}$

${ }^{5}$ ibid.[67].

${ }^{6}$ Sulistyowati Irianto, Perempuan Dan Hukum: Menuju Hukum Yang Berperspektif Kesetaraan Dan Keadilan (Yayasan Obor Indonesia 2006).

${ }^{7}$ Maidina Rahmawati dan Supriyadi Widodo Eddyono, Menuju Penguatan Hak Korban Dalam RUU Penghapusan Kekerasan Seksual (Institute for Criminal Justice Reform 2017).[6].

8 ibid. 
Perbedaan pendefinisian menjadi isu kriminalisasi dalam kasus kekerasan seksual menjadi rumit. ${ }^{9}$ World Health Organization (WHO) mendefinisikan kekerasan seksual sebagai: ${ }^{10}$

"any sexual act, attempt to obtain a sexual act, unwanted sexual comments or advances, or acts to traffic, or otherwise directed, against a person's sexuality using coercion, by any person regardless of their relationship to the victim, in any setting, including but not limited to home and work".

Apabila diterjemahkan secara bebas, kekerasan seksual menurut definisi WHO adalah "Semua perbuatan yang berhubungan dengan aktivitas seksual ataupun percobaan aktvitas seksual atau komentar atau perbuatan lainnya yang menyerang secara paksa seksualitas seseorang tanpa memandang hubungan yang dimiliki antara korban dan pelaku". Inisiatif-inisiatif pembahasan justru terfokus kepada kriminalisasi perbuatan kekerasan, melupakan persoalan yang lebih penting dan mendesak yaitu mengenai hak korban. ${ }^{11}$

Pembahasan tentang hak-hak korban menjadi luput dari perhatian karena semua perhatian seolah tertuju pada permasalahan kriminalisasi. Banyaknya peraturan perundang-undangan yang ada hanya menjelaskan secara rinci perbuatan yang dapat dijatuhi pidana, melupakan porsi pembahasan mengenai korban dan hak-hak korban. Korban sebagai pihak yang paling menderita seolah termarjinalisasi. Kekerasan seksual tidak hanya berdampak pada kesehatan fisik saja, tetapi juga berdampak pada mental dan sosial korban. ${ }^{12}$ Dalam situasi ini, negara seharusnya wajib memenuhi tanggung jawabnya atas hak-hak korban kekerasan seksual yang merupakan bagian dari HAM.

Beberapa undang-undang yang ada sebenarnya telah menguraikan beberapa hal yang menjadi hak korban kekerasan seksual. ${ }^{13}$ Hak-hak korban dimuat dalam berbagai undang-undang seperti UU Perlindungan Anak, UU

${ }^{9}$ ibid.

${ }^{10}$ World Health Organization, World Report on Violence and Health (UN World Health Organization 2002) (2002).

11 ibid.

12 ibid.

13 ibid 
PKDRT, Undang-Undang Nomor 13 Tahun 2006 tentang Perlindungan Saksi dan Korban sebagaimana telah diubah dengan Undang-Undang Nomor 31 Tahun 2014 (selanjutnya disebut UU Perlindungan Saksi dan Korban), dan UU PTPPO, namun, hak-hak tersebut hanya diatur secara normatif. Sementara itu, undangundang lainnya justru memuat hak-hak korban yang berbeda satu dengan yang lain, baik dari sisi penyelenggaraan hingga pelaksanaannya. ${ }^{14}$

Hal ini menjadi perhatian penulis karena sangat penting untuk adanya instrumen hukum di Indonesia yang dapat mencegah dan mengatasi permasalahanpermasalahan terkait kekerasan seksual serta memenuhi dan melindungi hakhak korban. Terseraknya pengaturan kekerasan seksual dan hak korban serta pemenuhannya menyebabkan persoalan kekerasan seksual menjadi permasalahan yang tidak terkoordinasi dan tidak komprehensif. Tidak ada ketentuan khusus yang menjamin bahwa korban mendapatkan hak-haknya sebagai korban kekerasan seksual. Saat ini, Indonesia telah meratifikasi Convention on the Elimination of All Forms of Discrimination Against Women (selanjutnya disebut CEDAW) melalui UndangUndang Nomor 7 Tahun 1984. Mengingat hal tersebut, maka penulis tertarik untuk menganalisis hal terkait khususnya perihal perlindungan hukum bagi korban kekerasan seksual di Indonesia dalam penanganan kasus-kasus kekerasan seksual mengingat banyaknya kasus kekerasan seksual yang tidak berkeadilan bagi korban.

Meskipun telah terdapat berbagai tulisan terkait perlindungan korban kekerasan seksual, namun belum ada yang membahasnya secara komprehensif. Pembahasan masih secara khusus terbatas pada korban kekerasan seksual pada anak, anak perempuan, maupun pada perempuan. Tulisan ini mencoba membahasnya secara lengkap dengan menggunakan perspektif HAM.

\section{Metode Penelitian}

Dalam penelitian ini penulis menggunakan metode penelitian yuridis normatif, yaitu penelitian yang menggunakan pendekatan masalah untuk 
mengkaji konsep-konsep dan hubungan dari berbagai ketentuan ${ }^{15}$ yang mengatur mengenai kekerasan seksual di Indonesia.

Untuk memecahkan isu hukum dalam tulisan ini, penulis menggunakan metode pendekatan perundang-undangan (statute approach) dan pendekatan konseptual (conceptual approach). Pendekatan perundang-undangan dilakukan dengan mengkaji segala peraturan perundang-undangan yang berkaitan dengan isu yang diteliti. ${ }^{16}$

Lalu pendekatan konseptual dilakukan dengan cara membangun konsep hukum melalui pandangan-pandangan dan doktrin-doktrin yang berkembang dalam ilmu hikum mengenai prinsip-prinsip hukum. ${ }^{17}$

\section{Pengaturan Kekerasan Seksual dalam Perspektif Hukum dan HAM}

Jeremy Bentham mengemukakan bahwa eksistensi manusia dikuasai oleh kesenangan dan penderitaan..$^{18}$ Perbuatan, norma, atau hukum, dapat dikatakan baik dan adil apabila memberikan kemanfaatan dan kebahagiaan terbesar bagi seluruh masyarakat atau setidak-tidaknya bagi mayoritas masyarakat. ${ }^{19}$ Utilitarianisme memprioritaskan kesejahteraan mayoritas sehingga sering kali sebagai akibatnya, minoritas atau individu akan dirugikan atau kehilangan hakhak dasarnya. Kecenderungan tirani mayoritas melekat pada teori utilitarian, beranjak dari sana maka lahirlah teori anti utilitarianisme sebagai anti tesis dari teori utilitarianisme. ${ }^{20}$

Berseberangan dengan teori utilitarianisme, Dworkin dan Nozick melontarkan kritik yang dikenal dengan teori anti utilitarianisme. Menurut Nozick, utilitarianisme mengorbankan kebebasan individu untuk mayoritas dan tidak mempertimbangkan fakta bahwa kehidupan seseorang individu

${ }^{15}$ Peter Mahmud Marzuki, Penelitian Hukum (Kencana 2005).[182].

16 ibid.[133].

17 ibid.[178].

${ }^{18}$ Besar, 'Utilitarianisme Dan Tujuan Perkembangan Hukum Multimedia Di Indonesia' (Binus University 2016).

${ }^{19}$ Alain Caille, 'Utilitarianism and Anti-Utilitarianism' (1992) 33 Sage Journal.

${ }^{20} \mathrm{ibid.}$ 
adalah satu-satunya kehidupan yang dimiliki olehnya. ${ }^{21}$ Individu tidak dapat dikorbankan tanpa persetujuannya untuk kepentingan masyarakat semata-mata sebagai alat atau sarana bagi yang lain. Tidak ada satu individu yang bernilai lebih dari individu lainnya. Negara bertanggungjawab untuk dapat melindungi setiap warga negara secara utuh dan setara. ${ }^{22}$

Salah satu bentuk komitmen dan keseriusan negara terkait pertanggungjawaban terhadap perlindungan hukum atas HAM adalah dengan meratifikasi instrumen internasional terkait HAM. Tanggung jawab Indonesia dalam perlindungan HAM bagi korban kekerasan seksual utamanya melalui diratifikasinya sejumlah instrumen hukum internasional tentang HAM yakni International Covenant on Civil and Political Rights (selanjutnya disebut ICCPR) dan CEDAW. Indonesia sebagai negara peserta berkewajiban memenuhi segala tanggung jawab dan memastikan hukum nasional Indonesia selaras dengan berbagai perjanjian-perjanjian internasional tersebut dan mekanisme-mekanisme yang menjadi kewajiban dari perjanjian-perjanjian internasional itu.

Selain instrumen hukum internasional, hukum nasional Indonesia juga telah memuat sejumlah ketentuan tentang kekerasan seksual. Ketentuan tersebut secara umum terdapat dalam UUD NRI Tahun 1945, Undang-Undang Nomor 39 Tahun 1999 tentang Hak Asasi Manusia (selanjutnya disebut UU HAM), dan KUHP. Lebih khusus lagi dalam sejumlah produk undang-undang diantaranya UU PKDRT, UU Perlindungan Anak, hingga UU PTPPO. Namun, berbagai ketentuan yang mengatur perlindungan terhadap korban kekerasan seksual dirasa masih belum cukup. Instrumen hukum terkait perlindungan korban kekerasan seksual belum dapat memberi payung hukum yang komprehensif. Hingga saat ini, belum ada peraturan perundang-undangan yang secara khusus mengatur tentang kekerasan seksual.

Sebelum masuk lebih jauh ke dalam pembahasan terkait perlindungan korban kekerasan seksual, definisi tentang korban harus dipahami terlebih dahulu.

\footnotetext{
${ }^{21}$ ibid.

${ }^{22}$ Yeyasa Sandang dan Eko Wijayanto, 'Konstruksi Konsep Hak Robert Nozick Dan John Rawls (Sebuah Komparasi Pemikiran)' (2017) 4 Jurnal Humaniora.[17].
} 
Secara konsep, korban atau victim, hanya dikenal oleh perspektif hukum terutama dalam hukum pidana dan HAM. Victim dikutip dan diterjemahkan secara bebas dari Oxford Dictionary didefinisikan sebagai “seseorang yang dilukai, terluka, atau terbunuh, sebagai hasil dari kejahatan, kecelakaan, atau peristiwa lain atau tindakan lain”. Kemudian KBBI, mendefinisikan korban sebagai “orang, binatang, dan sebagainya yang menjadi menderita (mati dan sebagainya) akibat suatu kejadian, perbuatan jahat, dan sebagainya". Selanjutnya, acuan mengenai definisi korban menurut hukum HAM internasional salah satunya adalah Declaration of Basic Principle of Justice for Victims of Crime and Abuse of Power atau Deklarasi Prinsip-Prinsip Dasar Keadilan Bagi Korban Kejahatan dan Penyalahgunaan Kekuasaan (selanjutnya disebut Deklarasi Prinsip-Prinsip Keadilan bagi Korban). Korban didefinisikan sebagai:

"persons who, individually or collectively, have suffered harm, including physical or mental injury, emotional suffering, economic loss or substantial impairment of their fundamental rights, through acts or omissions that are in violation of criminal laws operative within Member States, including those laws proscribing criminal abuse of power".

Apabila diterjemahkan, korban adalah orang orang yang, secara individu atau kolektif, telah menderita kerugian, termasuk luka fisik atau mental, penderitaan emosional, kerugian ekonomi atau perusakan yang substansial atas hak dasarnya, lewat tindakan atau pembiaran yang bertentangan dengan hukum pidana yang berlaku di negara-negara anggota termasuk hukum yang melarang penyalahgunaan kekuasaan yang bisa dikenai pidana. Sedangkan dalam perspektif hukum pidana Indonesia, definisi korban dapat ditemukan di dalam Pasal 1 angka 2 UU Perlindungan Saksi dan Korban. Dikatakan bahwa korban adalah seseorang yang mengalami penderitaan fisik, mental, dan/atau kerugian ekonomi yang diakibatkan oleh suatu tindak pidana. Dari definisi-definisi di atas, baik dalam perspektif HAM internasional melalui Deklarasi Prinsip-Prinsip Keadilan bagi Korban dan hukum pidana Indonesia melalui UU Perlindungan Saksi dan Korban, korban selalu identik dengan adanya tindak pidana. UU Perlindungan Saksi dan Korban sebagai bagian dari hukum pidana, tidak dapat dilepaskan dari KUHP 
dan undang-undang lain terkait hukum pidana. Kajian tentang korban kekerasan seksual dalam hukum pidana Indonesia akan dibahas lebih lanjut di bawah.

Sexual violence atau kekerasan seksual adalah istilah yang menjadi payung yang didalamnya termasuk berbagaijenis perbuatan seksual. WHOmendefinisikan sexual violence sebagai "Any sexual act, attempt to obtain a sexual act, unwanted sexual comments or advances, or acts to traffic or otherwise directed against a person's sexuality using coercion, by any person regardless of their relationship to the victim, in any setting, including but not limited to home and work" ${ }^{23}$ Sexual violence dalam definisi WHO dalam terjemahan bebas didefinisikan sebagai setiap tindakan seksual, upaya untuk mendapatkan tindakan seksual, komentar atau rayuan seksual yang tidak diinginkan, atau tindakan memperdagangkan seksualitas seseorang atau sebaliknya diarahkan terhadap seksualitas seseorang dengan paksaan, oleh siapapun, apapun hubungannya dengan korban, dalam situasi apapun, termasuk namun tidak terbatas pada rumah dan tempat kerja. ${ }^{24}$

\section{Perlindungan Korban Kekerasan dalam Instrumen Hukum Internasional}

Harkat dan martabat seorang manusia dalam instrumen hukum internasional dilindungi dengan berbagai macam pengaturan seperti hak atas keselamatan individu, hak kebebasan dan keamanan pribadi, dan perlindungan dari segala bentuk diskriminasi. Kebebasan dan keamanan pribadi dan hakhak yang terkait atasnya diatur dalam instrumen HAM internasional mulai dari Universal Declaration of Human Rights (selanjutnya disebut UDHR), ICCPR, maupun CEDAW, dan General Comment maupun General Recommendation yang menyertainya. Dikutip dan diterjemahkan dari United Nations, General Comment adalah interpretasi dari sebuah perjanjian terkait ketentuan, masalah tematik, atau cara kerja dari perjanjian internasional tentang HAM. ${ }^{25}$ Sedangkan General Recommendation adalah pernyataan otoritatif yang digunakan untuk memperjelas

\footnotetext{
${ }^{23}$ World Health Organization (n 10).[149].

${ }^{24}$ ibid

${ }^{25}$ United Nations, 'What Is the Purpose of the Human Rights Treaty Bodies General Comments' (Ask UN, 2020) <https://ask.un.org/faq/135547>.
} 
Luh Made: Perlindungan Hak Asasi...

laporan yang merupakan kewajiban negara pihak atau negara peserta dalam perjanjian. ${ }^{26}$ Berbagai instrumen hukum internasional tersebut merupakan dasar perlindungan baik langsung maupun tidak langsung terhadap korban kekerasan seksual.

\section{Universal Declaration of Human Rights (UDHR) 1948}

UDHR telah diakui sebagai prinsip umum hukum dan sumber yang memberikan kewajiban hukum bagi semua negara dan bahkan telah diadopsi oleh Mahkamah Internasional, ${ }^{27}$ meskipun dari segi hukum UDHR tidak mempunyai daya ikat, ketentuan-ketentuan yang terdapat di dalamnya telah banyak dimasukkan ke dalam hukum nasional negara-negara yang menjadi anggota PBB. UDHR telah dijadikan acuan ketika menilai pelaksanaan hakhak asasi manusia sebuah negara. ${ }^{28}$

Prinsip-prinsip dalam UDHR antara lain adalah pengakuan terhadap martabat dasar dan hak-hak yang sama dan sejajar sebagai dasar dari kemerdekaan, keadilan, dan perdamaian dunia, dan perlindungan HAM dengan rule of law. ${ }^{29}$ Disebutkan dalam Pasal 1 UDHR bahwa "All human beings are born free and equal in dignity and rights.", yang apabila diterjemahkan secara bebas artinya "Setiap orang, sejak dilahirkan, memiliki kebebasan dan memiliki persamaan martabat dan hak.". Selain itu, pada Pasal 3 UDHR yang berbunyi "Everyone has the right to life, liberty and the security of person." Dapat dilihat bahwa perlindungan terhadap kebebasan dan keselamatan individu adalah hal yang dijamin oleh UDHR.

${ }^{26}$ and Security LSE Centre for Women, Peace, 'General Recommendations' (LSE, 1992) $<$ https://blogs.lse.ac.uk/vaw/int/cedaw/general- recommendations/\#: :text=Under Article 21 of CEDAW,report obligat ions (e.g. requiring information>.report obligat ions (e.g. requiring information","author":[\{“dropping-particle":"", "family":"LSE Centre for Women, Peace","given":" and Security","'non-dropping-particle":"'","parse-names":false,"suffix":"'"\}],"container-title":"LSE","id":"ITEM-1", "issued":\{“date-parts":[[“1992"]]\},"title":"General Recommendations", "type":"webpage"],"uris":["http://www.mendeley.com/documents/?uuid=5413543b-b70f4c08-a7ec-9617b761744f"]\}],"mendeley":\{“formattedCitation":" and Security LSE Centre for Women, Peace, 'General Recommendations' (<i>LSE</i>, 1992

${ }^{27}$ Sekar Banjaran Aji, 'Memahami Standar Dan Instrumen Hak Asasi Manusia, Disampaikan Pada Pelatihan ACCESS III' (2019).

${ }^{28}$ Fika Yulialdina Hakim, 'International Humanitarian Law and Human Rights: Universal Declaration of Human Rights' (2007) 1 Indonesian Journal of International Law.

29 ibid.[135]. 


\section{International Covenant on Civil and Political Rights (ICCPR) 1966}

Selain UDHR, ketika membicarakan instrumen internasional mengenai HAM, setidaknya ada 2 (dua) instrumen utama lainnya yaitu, International Covenant on Economic, Social and Cultural Rights (selanjutnya disebut ICESCR) dan ICCPR beserta dua protokolnya. Ketiga instrumen ini dikenal sebagai The International Bill of Human Rights. ICCPR secara khusus ditujukan untuk mengukuhkan pokok-pokok HAM di bidang sipil dan politik yang tercantum dalam UDHR sehingga menjadi ketentuan-ketentuan yang mengikat secara hukum. Kovenan ini sendiri telah diratifikasi oleh Indonesia pada 28 Oktober 2005 melalui Undang-Undang Nomor 12 Tahun 2005 tentang Pengesahan International Covenant on Civil and Political Rights (Kovenan Internasional Tentang Hak-Hak Sipil dan Politik).

Pasal 9 Angka 1 ICCPR berbunyi "Everyone has the right to liberty and security of person. No one shall be subjected to arbitrary arrest or detention. No one shall be deprived of his liberty except on such grounds and in accordance with such procedure as are established by law." Yang apabila diterjemahkan, setiap orang berhak atas kebebasan dan keamanan pribadi. Jaminan bahwa tidak seorang pun dapat dirampas kebebasannya kecuali berdasarkan alasan-alasan yang sah sesuai dengan prosedur yang ditetapkan oleh hukum.

\section{General Comment No. 35 - Article 9: Liberty and Security of person 1982}

Proses adopsi dari General Comment yang membahas terkait Pasal 9 ICCPR tentang Liberty and Security of Person melalui perjalanan yang panjang. Butuh waktu 2 (dua) tahun dan dimulai dengan pembahasan dan pengajuan pendapat- pendapat yang berlangsung selama setengah hari. Pada bagian I angka 2 disebutkan bahwa:

"Article 9 recognizes and protects both liberty of person and security of person. In the Universal Declaration of Human Rights, article 3 proclaims that everyone has the right to life, liberty and security of person. That is the first substantive right protected by the Universal Declaration, which indicates the profound importance of article 9 of the Covenant both for individuals and for society as a whole. Liberty and security of person are precious for their own sake, and also because the deprivation of liberty and security of person have historically been 
principal means for impairing the enjoyment of other rights".

Perlindungan terhadap kebebasan dan keamanan pribadi diakui dalam Pasal 9 ICCPR yang juga dijamin dalam Pasal 3 UDHR. Hak atas kebebasan dan keamanan pribadi merupakan hak substantif pertama yang dilindungi oleh UDHR, ini mengindikasikan pentingnya pelindungan atas kebebasan dan keamanan pribadi, untuk individu dan masyarakat secara keseluruhan. Kebebasan dan keamanan pribadi sangat berharga bagi kepentingannya sendiri dan juga secara historis merupakan sarana utama dalam mengurangi pemenuhan terhadap hak-hak lainnya. Kemudian pada angka 3, disebutkan:

"Liberty of person concerns freedom from confinement of the body, not a general freedom of action.1 Security of person concerns freedom from injury to the body and the mind, or bodily and mental integrity, as further discussed in paragraph 9 below. Article 9 guarantees those rights to everyone. "Everyone" includes, among others, girls and boys, soldiers, persons with disabilities, lesbian, gay, bisexual and transgender persons, aliens, refugees and asylum seekers, stateless persons, migrant workers, persons convicted of crime, and persons who have engaged in terrorist activity".

Kebebasan seseorang menyangkut kebebasan dari segala bentuk penahanan tubuh, tidak hanya terkait kebebasan umum untuk berbuat sesuatu. Keamanan seseorang menyangkut bebas dari luka pada tubuh dan pikiran, harkat dan martabat seseorang. Pasal 9 ICCPR menjamin hak atas kebebasan dan keamanan ini untuk semua orang, termasuk di dalamnya perempuan dan lakilaki, tentara, orang dengan disabilitas, lesbian, gay, bisexual dan transgender, orang asing, pengungsi dan pencari suaka, orang stateless, pekerja migran, orang-orang yang dijatuhi pidana, dan orang-orang yang terlibat dalam aktivitas terorisme. ${ }^{30}$

\section{Convention on the Elimination of All Forms of Discrimination against Women (CEDAW) 1979}

CEDAW dirancang untuk memerangi segala bentuk diskriminasi terhadap perempuan. Semua manusia dilahirkan bebas dan sama dalam

${ }^{30}$ General Comment ICCPR, 'No. 35: Article 9' (1982). 
martabat dan hak dan bahwa tiap orang berhak atas semua hak dan kebebasan tanpa perbedaan apapun, termasuk perbedaan berdasarkan jenis kelamin. Kesetaraan dan keadilan antara laki-laki dan perempuan dalam segala bidang dan kegiatan merupakan penekanan yang ingin dicapai CEDAW. ${ }^{31}$ Indonesia sebagai salah satu negara peserta CEDAW telah meratifikasi CEDAW melalui Undang-Undang Nomor 7 Tahun 1984 tentang Pengesahan Konvensi tentang Penghapusan Segala Bentuk Diskriminasi terhadap Perempuan.

Dalam Pasal 2 CEDAW menyebutkan bahwa negara-negara peserta mengutuk diskriminasi terhadap perempuan dalam segala bentuknya dan bersepakat untuk menjalankan dengan segala cara yang tepat dan tanpa ditunda- tunda, kebijakan menghapus diskriminasi terhadap perempuan, dan untuk tujuan ini berusaha, diantaranya pada huruf b dan huruf c:

(b) To adopt appropriate legislative and other measures, including sanctions where appropriate, prohibiting all discrimination against women;

(c) To establish legal protection of the rights of women on an equal basis with men and to ensure through competent national tribunals and other public institutions the effective protection of women against any act of discrimination;

Ketentuan di atas dapat dimaknai bahwa negara-negara peserta CEDAW, memiliki kewajiban untuk membuat peraturan perundang-undangan yang tepat dan peraturan-peraturan lainnya termasuk sanksi-sanksinya di mana perlu dan melarang semua diskriminasi terhadap perempuan. Selain itu, negara peserta juga wajib menegakkan perlindungan hukum terhadap hak perempuan atas dasar yang sama dengan kaum laki-laki dan untuk menjamin melalui pengadilan nasional yang kompeten dan badan-badan pemerintah lainnya, perlindungan kaum perempuan yang efektif terhadap setiap tindakan diskriminasi.

Pada Pasal 2 huruf d CEDAW juga menyebutkan bahwa negaranegara peserta harus berusaha "To refrain from engaging in any act or practice of discrimination against women and to ensure that public authorities and institutions

${ }^{31}$ ibid 
shall act in conformity with this obligation." Ketentuan ini mengatur bahwa setiap negara peserta CEDAW memiliki kewajiban untuk tidak melakukan suatu tindakan atau praktek diskriminasi terhadap perempuan, dan untuk menjamin bahwa pejabat- pejabat pemerintah dan lembaga-lembaga negara akan bertindak sesuai dengan kewajiban tersebut.

Kemudian pada Pasal 6 CEDAW "States Parties shall take all appropriate measures, including legislation, to suppress all forms of traffic in women and exploitation of prostitution of women." Pasal ini membebankan kewajiban kepada negara-negara peserta CEDAW untuk menghapuskan segala bentuk perdagangan perempuan dan eksploitasi dari prostitusi perempuan, melalui berbagai upaya salah satunya pembentukan hukum nasional terkait larangan perdagangan dan eksploitasi prostitusi perempuan.

\section{General Recommendation No. 19: Violence Against women 1992}

Pada 1991, the Committee on the Elimination of Discrimination Against Women (Komite CEDAW) dalam sesinya yang kesebelas, membahas dan mempelajari Pasal 6 dan pasal-pasal lain dalam CEDAW yang menyangkut tentang kekerasan terhadap perempuan, kekerasan seksual dan eksploitasi perempuan. Komite CEDAW memperoleh suatu konklusi bahwa negaranegara peserta dalam CEDAW masih belum cukup mencerminkan relasi dekat antara diskriminasi terhadap perempuan, kekerasan berbasis gender, dan pelanggaran-pelanggaran HAM dan kebebasan yang fundamental. Beberapa rekomendasi spesifik dari Komite CEDAW diantaranya adalah:

(a) States parties should take appropriate and effective measures to overcome all forms of gender-based violence, whether by public or private act;

(b) States parties should ensure that laws against family violence and abuse, rape, sexual assault and other gender-based violence give adequate protection to all women, and respect their integrity and dignity. Appropriate protective and support services should be provided for victims. Gender-sensitive training of judicial and law enforcement officers and other public officials is essential for the effective implementation of the Convention;

(c) States parties should encourage the compilation of statistics and research on the extent, causes and effects of violence, and on the effectiveness of measures to prevent and deal with violence; 
Rekomendasi di atas meminta agar negara-negara peserta CEDAW berupaya secara efektif untuk mengantisipasi segala bentuk kekerasan berbasis gender, baik yang dilakukan oleh publik atau pribadi Salah satunya dengan membuat peraturan-peraturan hukum yang menentang kekerasan dan pelecehan keluarga, perkosaan, pelecehan seksual dan kekerasan berbasis gender, memberi proteksi yang seharusnya kepada semua perempuan, dan menghormati integritas dan kehormatan mereka. Selain itu, negaranegara peserta CEDAW harus berupaya untuk melindungi korban dengan menyediakan lembaga-lembaga bantuan yang cukup dan senantiasa dapat melayani para korban.

\section{Perlindungan Korban Kekerasan Seksual dalam Hukum Nasional}

Dalam konteks hukum nasional, UUD NRI Tahun 1945 dan peraturan perundang-undangan di bawahnya juga telah memberi jaminan tentang perlindungan harkat dan martabat manusia. Pada UUD NRI Tahun 1945, secara umum telah memuat jaminan perlindungan diri pribadi hingga jaminan kebebasan dari perlakuan yang merendahkan derajat martabat manusia. Peraturan perundang-undangan di bawahnya yang juga memberikan pengaturan terkait adalah UU HAM. Kemudian pengaturan hukum pidana terkait kekerasan seksual tersebar dalam KUHP, UU PKDRT, UU Perlindungan Anak, dan UU PTPPO. Jaminan perlindungan korban kekerasan seksual telah termuat dalam UUD NRI Tahun 1945 dan peraturan perundang-undangan di bawahnya.

1. Undang-Undang Dasar Negara Kesatuan Republik Indonesia Tahun 1945 (UUD NRI Tahun 1945)

Secara khusus terkait tentang perlindungan diri pribadi atas kehormatan, dan martabat dan juga terhadap penyiksaan atau perlakuan yang merendahkan derajat, martabat manusia diatur dalam Pasal 28G UUD NRI Tahun 1945 yang berbunyi sebagai berikut:

(1) Setiap orang berhak atas perlindungan diri pribadi, keluarga, kehormatan, martabat, dan harta benda yang di bawah kekuasaannya, serta berhak atas rasa aman dan perlindungan dari ancaman ketakutan 
untuk berbuat atau tidak berbuat sesuatu yang merupakan hak asasi.

(2) Setiap orang berhak untuk bebas dari penyiksaan atau perlakuan yang merendahkan derajat martabat manusia dan berhak memperoleh suaka politik dari negara lain.

Berdasarkan pasal-pasal tersebut, telah termuat jaminan atas perlindungan diri pribadi atas kehormatan, dan martabat dan juga terhadap penyiksaan atau perlakuan yang merendahkan derajat, martabat manusia. Sehingga perlindungan hukum bagi korban kekerasan seksual adalaah bagian dari hak konstitusional.

\section{Peraturan Perundang-undangan di Bawah UUD NRI Tahun 1945}

Secara umum, Pasal 29 ayat (1) UU HAM memberikan jaminan atas perlindungan diri pribadi atas kehormatan dan martabat seseorang. UU ini juga mengharuskan adanya perlindungan yang lebih terhadap kelompok yang rentan yang tertuang dalam Pasal 5 ayat (3). Penempatan mengenai HAM anak dan HAM perempuan dilakukan secara terpisah sebagai bentuk perlindungan sebagai bagian dari kekhususan kedua kelompok tersebut.. Hal ini sejalan dengan perkembangan internasional yang dibuktikan dengan adanya instrumen hukum internasional yang terpisah bagi anak dan perempuan. $^{32}$

Jaminan negara atas HAM tidak lahir karena ratifikasi peraturan internasional atau mengeluarkan peraturan apapun, namun negara bertanggungjawab dalam menjamin HAM warga negaranya yang telah dimiliki secara kodrati oleh manusia sejak kelahirannya dan memperlihatkan penghargaan negara atas atas hak-hak tersebut. ${ }^{33}$ Perempuan sebagai suatu kelompok masyarakat di dalam suatu negara, merupakan kelompok yang wajib dijamin hak- haknya. Negara berkewajiban untuk menjamin perlindungan HAM kelompok perempuan seperti kelompok lainnya. ${ }^{34}$

${ }^{32}$ ibid. [8].

${ }^{33}$ Niken Savitri, HAM Perempuan Kritik Teori Hukum Feminis Terhadap KUHP (Refika Aditama 2008).

34 ibid.[2]. 


\section{Peraturan Terkait Kekerasan Seksual dalam Hukum Pidana}

HAM baik laki-laki maupun perempuan diakui dan dilindungi oleh hukum. Hukum akan selalu dibutuhkan untuk mengakomodasi komitmen negara untuk melindungi hak asasi warga negaranya, termasuk perempuan. Indonesia melalui hukum positifnya sudah seharusnya menjamin perlindungan terhadap perempuan korban kekerasan. KUHP mengatur tindak pidana kekerasan melalui rumusan pasal-pasalnya, antara lain yang terdapat dalam babbab tentang kejahatan terhadap kesusilaan, kejahatan terhadap nyawa, tentang penganiayaan dan tentang mati atau luka-luka karena kealpaan. ${ }^{35}$ Namun, KUHP tidak mengatur secara khusus tentang tindak pidana kekerasan yang tidak berakibat luka secara fisik, misalnya pelecehan, celaan, ataupun kekerasan verbal yang lebih mengakibatkan perlukaan psikis tidak diatur dalam KUHP. Pasal yang mengatur tentang kekerasan seksual juga tidak dapat ditemukan dalam KUHP.

Dalam KUHP tindak pidana kekerasan diatur dengan melindungi korban kekerasan baik yang berjenis kelamin laki-laki maupun perempuan, yaitu jenis kekerasan yang berakibat pada perlukaan fisik. Untuk kekerasan yang korbannya hanya berjenis kelamin perempuan dapat ditemukan dalam bentukbentuk kekerasan seksual yang diatur dalam Pasal 285, 286, 287, 288, dan 297. Pasal-pasal tersebut berada di bawah Bab XIV KUHP tentang kejahatan terhadap kesusilaan. ${ }^{36}$ Pasal 285 berbunyi "Barangsiapa dengan kekerasan atau ancaman kekerasan memaksa seorang wanita bersetubuh dengan dia di luar perkawinan diancam karena melakukan perkosaan, dengan pidana penjara paling lama duabelas tahun." Kemudian Pasal 286 berbunyi "Barangsiapa bersetebuh dengan seorang wanita di luar perkawinan, padahal diketahui bahwa wanita itu dalam keadaan pingsan atau tidak berdaya, diancam dengan pidana paling lama sembilan tahun." Selanjutnya, Pasal 287 mengatur tentang persetubuhan dengan wanita di bawah umur. Pasal 288 mengatur tentang persetubuhan dengan wanita

\footnotetext{
${ }^{35}$ ibid.[4].

${ }^{36}$ ibid.[10].
} 
di bawah umur yang mengakibatkan luka, luka berat, atau kematian. Sedangkan Pasal 297 mengatur tentang perdagangan wanita dan anak laki-laki yang belum cukup umur.

Pengaturan tindak pidana kekerasan dalam KUHP tampak dimaksudkan untuk mengatur kesusilaan seseorang dan bukan melindungi perempuan yang menjadi korban dalam tindak pidana tersebut. ${ }^{37}$ Istilah yang digunakan kejahatan terhadap kesusilaan. Padahal kesusilaan menitikberatkan pada pengaturan tentang susila dan kesopanan, bukan pada perlindungan perempuan. Kejahatan terhadap kesusilaan juga menitikberatkan pada tempat terjadinya kejahatan yaitu ruang publik. ${ }^{38} \mathrm{KUHP}$ yang berlaku di Indonesia saat ini adalah peninggalan masa kolonialisme Belanda. Semula, Indonesia mengalami dualisme dalam hukum pidana akibat pemisahan antara hukum pidana yang berlaku untuk orang-orang Eropa dengan hukum pidana yang berlaku untuk orang-orang Indonesia dan Timur Asing. Pada orang-orang Eropa berlaku Staatsblad 1866 Nomor 55, sedangkan untuk orang-orang Indonesia dan Timur Asing berlaku Ordonantie. Keduanya merupakan jiplakan dari Code Penal Perancis yang oleh Kaisar Napoleon diberlakukan juga di Belanda pada saat Belanda dalam jajahan Perancis. Berlakunya asas konkordansi mengakibatkan berlakunya hukum pidana Perancis di Belanda. Secara tidak langsung, Indonesia yang merupakan wilayah jajahan Belanda, berlaku pula asas konkordansi. ${ }^{39}$

KUHP yang berlaku saat ini, yang memuat aturan tentang kekerasan tersebut, adalah peninggalan Belanda sejak1918, pengganti KUHP yang berlaku sebelumnya. Larangan-larangan sentralistik pada KUHP di Belanda yang merupakan hukum pidana Perancis mencerminkan keinginan penguasa untuk membuat aturan yang dipatuhi oleh warga negaranya. Hal ini berakibat pada pengaturan hukum pidana yang terkodifikasi yang berimplikasi pada kecenderungan positivistik. ${ }^{40}$

\footnotetext{
37 ibid.[11].

38 ibid.[5].

${ }^{39}$ ibid.[6].

40 ibid.
} 
Upaya pembaruan KUHP telah coba dilakukan sejak puluhan tahun silam, gagasan rekodefikasi KUHP pertama kali muncul saat digelarnya Seminar Hukum Nasional I yang dilaksanakan di Semarang pada tahun 1963. Seminar ini menjadi titik awal sejarah pembaruan KUHP di Indonesia yang setahun kemudian mulai dirumuskan oleh tim bentukan pemerintah. ${ }^{41}$ Pembahasan Rancangan KUHP (selanjutnya disebut RKUHP) ini mengalami pasang surut lebih dari setengah abad lamanya, tak kunjung rampung dibahas dan disahkan. Saat ini, RKUHP masuk ke dalam daftar Program Legislasi Nasional (Prolegnas) periode 2020-2024 dan telah berada pada proses Pembicaraan Tingkat II. RKUHP ini membuka kemungkinan perubahan pasal-pasal yang mengatur kesusilaan.

Namun, hingga draft yang terakhir beredar di publik pada September 2019 lalu, RKUHP justru dianggap suatu kemunduran terhadap perlindungan korban kekerasan seksual. Pasal 417 RKUHP, misalnya, mendefinisikan persetubuhan di luar perkawinan sebagai tindak pidana, meski hal ini merupakan delik aduan yang hanya bisa dilaporkan orangtua, suami, istri atau anak. ${ }^{42}$ Perluasaan makna perzinaan menjadi setiap hubungan seksual di luar perkawinan ini berpotensi menimbulkan terjadinya overkriminalisasi dan justru kontra produktif terhadap perlindungan korban kekerasan seksual. Pelaku utama kekerasan seksual dalam ranah personal adalah pacar dan disusul anggota keluarga dekat. ${ }^{43}$ Kekhawatiran bahwa korban kekerasan seksual akan semakin sulit memperoleh keadilan karena hubungannya dianggap sesuatu yang konsensual dan justru dapat dipidana. Hal ini tentu kontraproduktif dengan usaha penghapusan kekerasan seksual.

Tindak pidana kekerasan yang tidak berakibat luka secara fisik, misalnya pelecehan, celaan, ataupun kekerasan verbal yang lebih mengakibatkan perlukaan psikis baru diatur dalam UU PKDRT. UU PKDRT disahkan pada 22 September

\footnotetext{
${ }^{41}$ Agus Sahbani, 'Sekilas Sejarah Dan Problematika Pembahasan RKUHP' (Hukum Online, 2020) <https://www.hukumonline.com/berita/baca/lt5a42131b82c60/sekilas-sejarah-dan- problematika-pembahasan-rkuhp/>.

${ }^{42}$ Gita Putri Damayana, 'Pelemahan Perlindungan Terhadap Perempuan Di Era Reformasi Dalam Agenda RUU PKS Dan RKUHP (Pusat Studi Hukum Dan Kebijakan Indonesia 2020)' $<$ https://pshk.or.id/blog-id/pelemahan-perlindungan-terhadap-perempuan-di-era-reformasi-dalam-agenda-ruu-pks-dan-rkuhp/>.

${ }^{43}$ Komnas Perempuan (n 2). Op.Cit.[15].
} 
2004 mengatur larangan tindak kekerasan dalam rumah tangga terhadap orang dalam lingkup rumah tangga. Larangan kekerasan fisik, psikis, seksual, dan penelantaran dalam rumah tangga. ${ }^{44}$ Istilah kekerasan seksual sendiri baru muncul dalam undang-undang ini. Dalam Pasal 8 UU PKDRT disebutkan ruang lingkup kekerasan seksual yaitu “...a. pemaksaan hubungan seksual yang dilakukan terhadap orang yang menetap dalam lingkup rumah tangga tersebut; b. pemaksaan hubungan seksual terhadap salah seorang dalam lingkup rumah tangganya dengan orang lain untuk tujuan komersial dan/atau tujuan tertentu." Namun demikian, tidak ada penjelasan atau definisi tentang kekerasan seksual.

Secara khusus tentang perlindungan anak dari kekerasan seksual, telah diatur dalam UU Perlindungan Anak. Dalam Pasal 15 huruf f UU Perlindungan Anak disebutkan bahwa "Setiap Anak berhak untuk memperoleh perlindungan dari: ...f. kejahatan seksual.". UU Perlindungan Anak memberikan perlindungan pada anak sebagai korban kekerasan seksual. Namun, UU Perlindungan Anak juga tidak memberikan definisi atau penjelasan terkait kejahatan maupun kekerasan seksual.

Salah satu bentuk kekerasan seksual lainnya yaitu eksploitasi seksual telah diatur pula dalam UU PTPPO. Pasal 1 angka 8 UU PTPPO memberikan definisi terkait eksploitasi seksual sebagai "segala bentuk pemanfaatan organ tubuh seksual atau organ tubuh lain dari korban untuk mendapatkan keuntungan, termasuk tetapi tidak terbatas pada semua kegiatan pelacuran dan percabulan.". Perdagangan orang khususnya eksploitasi seksual merupakan tindakan yang bertentangan dengan harkat dan martabat manusia dan melanggar HAM sehingga harus diberantas. Meluasnya jaringan kejahatan perdagangan orang yang terorganisir baik antarnegara maupun dalam negeri menjadi ancaman pada penghormatan terhadap HAM.

Korban Tindak Pidana Perdagangan Orang (TPPO) tidak hanya untuk tujuan pelacuran atau bentuk eksploitasi seksual lainnya, tetapi juga mencakup bentuk eksploitasi lain. Mayoritas kasus TPPO di Indonesia mencakup eksploitasi

${ }^{44}$ ibid.[1]. 
ketenagakerjaan, eksploitasi seksual, pekerjaan yang tidak sesuai dengan perjanjian, penjualan organ tubuh, dan kasus bayi yang diperjualbelikan. TPPO telah menjadi kejahatan luar biasa yang memerlukan penanganan khusus. ${ }^{45}$

Aspek pencegahan dalam upaya pemberantasan perdagangan orang berdasarkan UU PTPPO merupakan bagian yang cukup signifikan. Begitu pula dengan aspek penghukuman, selain berfungsi untuk penindakan terhadap pelaku juga memberi andil terhadap upaya pencegahan perdagangan orang. Sanksi pidana yang cukup berat idealnya dapat mencegah terjadinya tindak pidana perdagangan orang. Namun demikian, fenomena yang terjadi terkait praktik tindak pidana perdagangan orang justru semakin marak terjadi. ${ }^{46}$

Hukum pidana yang mengatur tentang kekerasan seksual masih tersebar dalam beberapa undang-undang. Kekerasan seksual yang meliputi perkosaan, pelecehan seksual, sentuhan yang tidak diinginkan, pemaksaan hubungan seksual, perdagangan seksual, sunat perempuan, pencabulan, perkawinan anak, pemaksaan kontrasepsi, perbudakan seksual, pemaksaan prostitusi, hingga pemaksaan kehamilan secaara terpisah diatur dalam berbagai undang-undang. Ketika KUHP tidak memberikan pengaturan tentang kekerasan seksual, berlaku asas lex specialis derogat legi generali. Asas ini adalah asas penafsiran hukum yang menyatakan bahwa hukum yang khusus mengesampingkan hukum yang bersifat umum. Namun permasalahannya, belum ada hukum yang secara khusus mengatur tentang kekerasan seksual. Sehingga dalam kasus yang tidak dapat diselesaikan dengan UU PKDRT, UU Perlindungan Anak dan UU PTPPO misalnya, aparat penegak hukum akan kembali pada hukum pidana umum yaitu KUHP.

Dalam bidang hukum pidana, KUHP dibatasi oleh asas legalitas yang diatur dalam Pasal 1 ayat (1) yang isinya "Tidak ada suatu perbuatan pun yang dilarang (diharuskan) dan diancam dengan pidana, kalau hal itu sebelumnya tidak dinyatakan dalam suatu ketentuan undang-undang yang telah ada terlebih dahulu daripada perbuatannya itu sendiri". Dengan adanya ketentuan tersebut,

\footnotetext{
${ }^{45}$ ibid. [3].
}

${ }^{46}$ ibid.[11]. 
KUHP tidak dapat digunakan sebagai dasar dalam kejahatan yang tidak diatur dalam hukum tertulis. Telah jelas tersurat bahwa adanya persyaratan yang tidak memungkinkan adanya kejahatan dan pelanggaran lain di luar aturan yang telah ditulis untuk dilarang. ${ }^{47}$

Terlihat bahwa baik dari latar belakang sejarah KUHP dari segi tujuannya adalah untuk mencegah kesewenang-wenangan penguasa dalam menggunakan hukum pidana. Tiada suatu pengaturan pun yang dapat menyimpangi dari yang sudah digariskan dalam asas legalitas KUHP. Pengaruh positivisme dalam pemberlakuan Pasal 1 ayat (1) mempersempit setiap usaha penafsiran sebagai bagian dari kepastian hukum. Kepastian hukum demi keadilan yang dinyatakan dalam Pasal 1 ayat (1) telah dimaknai sebagai tidak dimungkinkannya ruang penafsiran sebagai benteng untuk meminimalisir dijatuhkannya hukuman terhadap seseorang yang melakukan perbuatan yang tidak dilarang secara tegas dan tertulis dalam suatu perundangan pidana. ${ }^{48}$

Perlindungan bagi korban kekerasan seksual di peraturan perundangundangan di Indonesia masih tersebar di beberapa peraturan peraturan perundang-undangan, seperti di KUHP, UU PKDRT, UU Perlindungan Anak, dan UU PTPPO. Tidak ada suatu undang-undang khusus yang mengatur tentang perlindungan terhadap korban kekerasan seksual. Instrumen hukum terkait perlindungan korban kekerasan seksual yang ada saat ini, belum dapat memberi payung hukum yang komprehensif.

KUHP masih menjadi acuan utama dalam hukum pidana Indonesia termasuk ketika dihadapkan pada kasus kekerasan seksual. Istilah kekerasan seksual tidak dapat ditemukan di dalam KUHP, lebih-lebih definisi terkait korban kekerasan seksual. Namun, definisi korban dapat kita peroleh melalui analisis pasal-pasal dalam KUHP yang mengatur tentang kekerasan seksual, khususnya Pasal 285 dan Pasal 286 KUHP. Kedua pasal tersebut sama-sama mengatur tentang tindak pidana perkosaan, tetapi yang membedakan keduanya adalah keadaan wanita

\footnotetext{
${ }^{47}$ Niken Savitri (n 33).Op.Cit.[64].

${ }^{48}$ ibid. [8].
} 
yang menjadi korban. Pasal 285 KUHP mengatur pemaksaan persetubuhan, dengan kekerasan atau ancaman kekerasan, terhadap wanita di luar perkawinan, sedangkan Pasal 286 KUHP mengatur tentang persetubuhan, pada seorang wanita di luar perkawinan, yang diketahui dalam keadaan pingsan atau tidak berdaya. Kedua pasal tersebut mensyaratkan perbuatan dilakukan terhadap wanita dan pelakunya harus laki-laki. Tidak dimungkinkan adanya perbuatan Pasal 285 dan 286 KUHP yang dilakukan terhadap laki-laki dengan pelaku perempuan.

Unsur persetubuhan sendiri menurut R. Soesilo diartikan sebagai adanya peraduan antara kemaluan laki-laki ke dalam kemaluan perempuan hingga mengeluarkan air mani. Hal ini tentu sangat sempit mengingat kasus-kasus kekerasan seksual yang terjadi tidak selalu demikian. Keseluruhan unsur-unsur dalam kedua pasal tersebut juga harus dipenuhi secara kumulatif sehingga memenuhi delik dari pasal-pasal tersebut. Ketika salah satu unsur dalam rumusan delik tidak dapat terpenuhi, maka perbuatan tersebut tidak dapat diklasifikasikan sebagai sebuah perbuatan pidana karena tindak pidana belum atau tidak terjadi. ${ }^{49}$

Undang-undang terkait kekerasan seksual diantaranya UU PKDRT, UU Perlindungan Anak, UU PTPPO masing-masing memuat definisi 'korban'. Korban yang dilindungi UU PKDRT diatur dalam Pasal 1 angka 3 UU PKDRT yang mendefinisikan korban sebagai “orang yang mengalami kekerasan dan/ atau ancaman kekerasan dalam lingkup rumah tangga." UU Perlindungan Anak yang mengatur secara khusus tentang perlindungan anak, melalui Pasal 1 angka 1 memberikan batasan melalui definisi anak sebagai "seseorang yang belum berusia 18 (delapan belas) tahun, termasuk anak yang masih dalamkandungan." Kemudian dalam tindak pidana perdagangan orang, ruang lingkup korban dibatasi melalui Pasal 1 angka 3 UU PTPPO, yakni “seseorang yang mengalami penderitaan psikis, mental, fisik, seksual, ekonomi, dan/atau sosial, yang diakibatkan tindak pidana perdagangan orang". Padahal korban-korban kekerasan seksual tidak hanya

${ }^{49}$ Arif Maulana, 'Mengenal Unsur Tindak Pidana Dan Syarat Pemenuhannya' (Hukumonline, 2020) <https://www.hukumonline.com/klinik/detail/ulasan/lt5236f79d8e4b4/mengenal- unsurtindak-pidana-dan-syarat-pemenuhannya/>. 
terbatas pada korban dalam KUHP, korban dalam ranah rumah tangga, korban anak, dan korban perdagangan orang saja. Korban- korban kekerasan seksual di luar kesemua itu tentu membutuhkan perlindungan yang sama. Dengan tidak adanya aturan yang komprehensif, upaya perlindungan korban kekerasan seksual menjadi tidak maksimal.

Upaya perbaikan perlindungan terhadap peraturan perundang-undangan terkait kekerasan telah secara aktif dilakukan oleh koalisi masyarakat sipil dengan mengajukan kertas kebijakan dan Rancangan Undang-Undang Penghapusan Kekerasan Seksual (selanjutnya disebut RUU PKS). RUU PKS ditujukan untuk mencegah dan menangani kasus-kasus kekerasan seksual dan menyediakan rehabilitasi korban serta hukuman terhadap pelaku kekerasan seksual. RUU PKS juga mengemukakan prosedur hukum khusus bagi penanganan kasus kekerasan seksual untuk menghilangkan hambatan bagi korban kekerasan seksual dan meningkatkan akses bantuan hukum bagi para perempuan yang selama ini mengalami kesulitan dalam menyelesaikan kasusnya melalui pengadilan. ${ }^{50}$

\section{Kesimpulan}

Perlindungan hukum bagi korban kekerasan seksual dapat dimaknai sebagai bagian dari HAM yaitu hak atas keselamatan individu, hak kebebasan dan keamanan pribadi, dan perlindungan diri atas kehormatan dan martabat seseorang yang secara kodrati melekat pada manusia sejak kelahirannya. Perlindungan hukum bagi korban kekerasan seksual dapat dilacak dari instrumen internasional tentang HAM, diantaranya UDHR (Pasal 1), ICCPR (Pasal 9 angka 1), dan CEDAW (Pasal 2 dan Pasal 6). Pada tingkat nasional terdapat pada UUD NRI Tahun 1945 (Pasal 28G) dan UU HAM (Pasal 29 ayat (1)). Hukum pidana yang mengatur tentang tindak pidana kekerasan seksual tersebar di beberapa ketentuan, diantaranya KUHP melalui Pasal 285-288 dan Pasal 297, UU PKDRT,

${ }^{50} \mathrm{OHCHR}$, 'Indonesian National Commission on Violence against Women, National Human Rights Independent Report: Regarding the Implementation of the Convention on the Elimination of All Forms of Discrimination Againts Women in Indonesia' (Office of the United Nations High Commissioner for Human Rights, 2016) <www./tbinternet.ohchr.org>. 
UU Perlindungan Anak, dan UU PTPPO.

Perlindungan bagi korban kekerasan seksual di peraturan perundangundangan di Indonesia sudah ada namun masih tersebar di beberapa peraturan peraturan perundang-undangan, seperti di KUHP, UU PKDRT, UU Perlindungan Anak, dan UU PTPPO. Instrumen hukum terkait perlindungan korban kekerasan seksual yang ada saat ini, belum dapat memberi payung hukum yang komprehensif. Tidak adanya suatu undangundang khusus yang mengatur tentang perlindungan terhadap korban kekerasan seksual menjadikan perlindungan bagi korban kekerasan seksual menjadi tidak maksimal.

\section{Daftar Bacaan}

\section{Buku}

Bahder Johan Nasution, Negara Hukum Dan Hak Asasi Manusia (Mandar Maju 2018).

Besar, 'Utilitarianisme Dan Tujuan Perkembangan Hukum Multimedia Di Indonesia' (Binus University 2016).

Komnas Perempuan, Kekerasan Meningkat: Kebijakan Penghapusan Kekerasan Seksual Untuk Membangun Ruang Aman Bagi Perempuan Dan Anak Perempuan (Catatan Kekerasan Terhadap Perempuan Tahun 2019) (2020).

Maidina Rahmawati dan Supriyadi Widodo Eddyono, Menuju Penguatan Hak Korban Dalam RUU Penghapusan Kekerasan Seksual (Institute for Criminal Justice Reform 2017).

Niken Savitri, HAM Perempuan Kritik Teori Hukum Feminis Terhadap KUHP (Refika Aditama 2008).

Peter Mahmud Marzuki, Penelitian Hukum (Kencana 2005).

Sulistyowati Irianto, Perempuan Dan Hukum: Menuju Hukum Yang Berperspektif Kesetaraan Dan Keadilan (Yayasan Obor Indonesia 2006).

\section{Jurnal}

Alain Caille, 'Utilitarianism and Anti-Utilitarianism' (1992) 33 Sage Journal. 
Fika Yulialdina Hakim, 'International Humanitarian Law and Human Rights: Universal Declaration of Human Rights' (2007) 1 Indonesian Journal of International Law.

Yeyasa Sandang dan Eko Wijayanto, 'Konstruksi Konsep Hak Robert Nozick Dan John Rawls (Sebuah Komparasi Pemikiran)’ (2017) 4 Jurnal Humaniora.

\section{Laman}

Agus Sahbani, 'Sekilas Sejarah Dan Problematika Pembahasan RKUHP' (Hukum Online, 2020) <https://www.hukumonline.com/berita/baca/ lt5a42131b82c60/sekilas-sejarah-dan- problematika-pembahasan-rkuhp/>.

Arif Maulana, 'Mengenal Unsur Tindak Pidana Dan Syarat Pemenuhannya' (Hukumonline, 2020) .<https://www.hukumonline.com/klinik/detail/ ulasan/lt5236f79d8e4b4/mengenal- unsur-tindak-pidana-dan-syaratpemenuhannya/>.

Gita Putri Damayana, 'Pelemahan Perlindungan Terhadap Perempuan Di Era Reformasi Dalam Agenda RUU PKS Dan RKUHP (Pusat Studi Hukum Dan Kebijakan Indonesia 2020)' <https://pshk.or.id/blog-id/pelemahanperlindungan-terhadap-perempuan-di-era-reformasi-dalam-agenda-ruupks-dan-rkuhp/>.

LSE Centre for Women, Peace and S, 'General Recommendations' (LSE, 1992) <https://blogs.lse.ac.uk/vaw/int/cedaw/generalrecommendations/\#: :text=Under Article 21 of CEDAW,report obligat ions (e.g. requiring information>.

United Nations, 'What Is the Purpose of the Human Rights Treaty Bodies General Comments' (Ask UN, 2020) <https:/ /ask.un.org/faq/135547>.

World Health Organization, World Report on Violence and Health (UN World Health Organization 2002).

\section{Pelatihan}

OHCHR, 'Indonesian National Commission on Violence against Women, National Human Rights Independent Report: Regarding the Implementation of the Convention on the Elimination of All Forms of Discrimination Againts Women in Indonesia' (Office of the United Nations High Commissioner for Human Rights, 2016) <www./tbinternet.ohchr.org>.

General Comment ICCPR, ‘No. 35: Article 9’ (1982). 
Sekar Banjaran Aji, 'Memahami Standar Dan Instrumen Hak Asasi Manusia, Disampaikan Pada Pelatihan ACCESS III' (2019).

\section{Perundang-undangan}

Undang-Undang Dasar Negara Republik Indonesia Tahun 1945 Kitab UndangUndang Hukum Pidana.

Undang-Undang Nomor 7 Tahun 1984 tentang Pengesahan Convention on the Elimination of All Forms Discrimination Against Women (Konvensi tentang Penghapusan Segala Bentuk Diskriminasi terhadap Perempuan) (Lembaran Negara Republik Indonesia Tahun 1984 Nomor 29).

Undang-Undang Nomor 39 Tahun 1999 tentang Hak Asasi Manusia (Lembaran Negara Republik Indonesia Tahun 1999 Nomor 65).

Undang-Undang Nomor 23 Tahun 2004 tentang Penghapusan Kekerasan Dalam Rumah Tangga (Lembaran Negara Republik Indonesia Tahun 2004 Nomor 95).

Undang-Undang Nomor 12 Tahun 2005 tentang Pengesahan International Covenant on Civil and Political Rights (Kovenan Internasional tentang Hak-Hak Sipil dan Politik) (Lembaran Negara Republik Indonesia Tahun 2005 Nomor 119).

Undang-Undang Nomor 21 Tahun 2007 tentang Pemberantasan Tindak Pidana Perdagangan Orang (Lembaran Negara Republik Indonesia Tahun 2007 Nomor 58).

Undang-Undang Nomor 31 Tahun 2014 tentang Perubahan Undang-Undang Nomor 13 Tahun 2006 tentang Perlindungan Saksi dan Korban (Lembaran Negara Republik Indonesia Tahun 2014 Nomor 293).

Undang-Undang Nomor 35 Tahun 2014 tentang Perubahan Atas Undang-Undang Nomor 23 tahun 2002 tentang Perlindungan Anak (Lembaran Negara Republik Indonesia Tahun 2014 Nomor 297).

How to cite: Luh Made Khristianti Weda Tantri, 'Perlindungan Hak Asasi Manusia Bagi Korban Kekerasan Seksual di Indonesia' (2021) Vol. 4 No. 2 Media Iuris. 
--Halaman ini sengaja dibiarkan kosong-- 